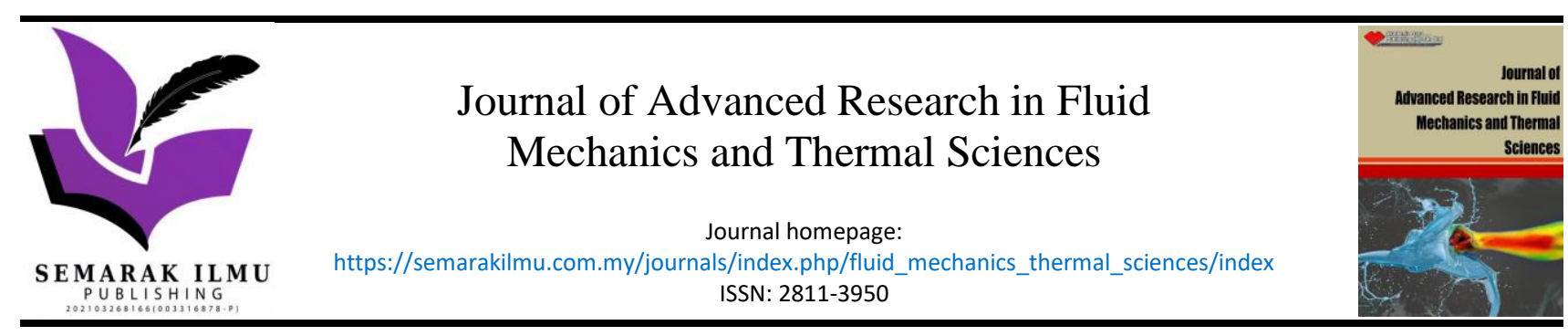

\title{
Experimental Test on Aerodynamic Performance of Propeller and Its Effect on The Flight Performance of Serindit V-2 UAV
}

\author{
Kaspul Anuar ${ }^{1, *}$, Musthafa Akbar ${ }^{1}$, Hanif Abdul Aziz ${ }^{1}$, Agung Soegihin $^{1}$ \\ 1 Department of Mechanical Engineering, Universitas Riau, Indonesia
}

\section{ARTICLE INFO}

\section{Article history:}

Received 26 September 2021

Received in revised form 11 December 2021

Accepted 15 December 2021

Available online 26 January 2022

\section{Keywords:}

Aerodynamic performance; serindit V-2; UAV; flight test

\section{ABSTRACT}

The Serindit V-2 is a flying vehicle (UAV) that was successfully developed to participate in the Indonesian Flying Robot Contest with a mission to fly at high speed and acceleration. The purpose of this research is to obtain the optimum aerodynamic performance of the propeller and its effect to the flight performance of the Serindit V2 Unmanned Aerial Vehicle (UAV). The study began by testing the aerodynamic performance of propellers (static thrust value, time consumed, and power consumed) with different sizes of propellers, ranging from 8 inches to 12 inches. From the test results, the 12 -inch propeller at $100 \%$ throttle generates the highest thrust value of $29.607 \mathrm{~N}$, time consumed of 4.91 minutes, and power consumed of 717.57 Watt. The study was continued by calculating the flight performance with the results that the maximum speed value was $24.11 \mathrm{~m} / \mathrm{s}$, the rate of climb was $3.347 \mathrm{~m} / \mathrm{s}$, and the stall speed was $14.6 \mathrm{~m} / \mathrm{s}$. Finally, the Serindit V-2 UAV was tested to fly using a propulsion system with a 12 -inch propeller and varied throttle opening from $50 \%$ to $100 \%$. The test results show the vehicle's maximum speed of $24,562 \mathrm{~m} / \mathrm{s}$ is obtained at a throttle opening of $100 \%$. The climb rate and the flight time at $100 \%$ throttle opening is 2,656 $\mathrm{m} / \mathrm{s}$ and 3 minutes 27 seconds, while the vehicle's stall speed during cruising flight (angle of attack at 1 degree) is $13 \mathrm{~m} / \mathrm{s}$. The difference between the theoretical calculation results and the actual test is at least caused by 2 factors. The first is the aerodynamic factor, in theoretical calculations, the overall aerodynamic design of the aircraft is considered very smooth/seamless. This has an impact on the fluid flow that occurs on the aircraft. On the actual conditions, the vehicle has several parts that cause drag, such as the pitot sensor located at the tip of the right-wing, and the ballast located on the left-wing.

\section{Introduction}

An unmanned Aerial Vehicle (UAV) is an aircraft that is controlled without the presence of a pilot on board. The UAV utilizes aerodynamic forces in the form of lift force generated by the wings [1, 2]. Based on the type of wing, the UAV is divided into two types, which are the rotary wing and the fixedwing. The fixed-wing UAV has an advantage in terms of efficiency because the propulsion system is only used to generate thrust for the aircraft $[3,4]$. In its application, fixed-wing UAVs are used to

\footnotetext{
* Corresponding author.

E-mail address: Kaspul.anuar@lecturer.unri.ac.id
}

https://doi.org/10.37934/arfmts.91.2.120132 
monitor agricultural, plantation, and mining areas [5]. In addition, in the military field, UAVs are also used for combat missions [6]. Serindit V-2 is an UAV developed by the Mechanical Engineering Research Team of Riau University [7]. The development process of Serindit V-2 was started from the design process, molding process, airframe construction process, electronic component assembly, and flight test. Based on these tests, the Serindit V-2 UAV managed to fly stably at an altitude of 150 meters above ground level.

Serindit V-2 was developed to participate in the Indonesian Flying Robot Contest (KRTI) with a mission to fly at high both speed and acceleration. According to the regulation of the contest, UAV should be able to complete as many tracks as possible within three minutes [8]. To obtain the optimum flight performance of Serindit V-2, in this study, research was carried out to find the optimum aerodynamic performance of the propeller. The optimum aerodynamic performance of the propeller is determined based on the highest thrust value and eligible battery consumption time (more than or equal to three minutes).

\section{Fundamental Theory}

\subsection{Aerodynamic Performance of Propeller}

Propellers are widely used in the aerial vehicles including unmanned aerial vehicles and small aircraft. Generally, propellers are made using carbon fiber, metal, or plastic materials. The aerodynamic performance of the propeller such as the static thrust value, rotational speed, time consumed, and power consumed greatly determines the flight performance of the UAV. Figure 1 shows the blade element of a propeller with the corresponding aerodynamic forces and velocities.

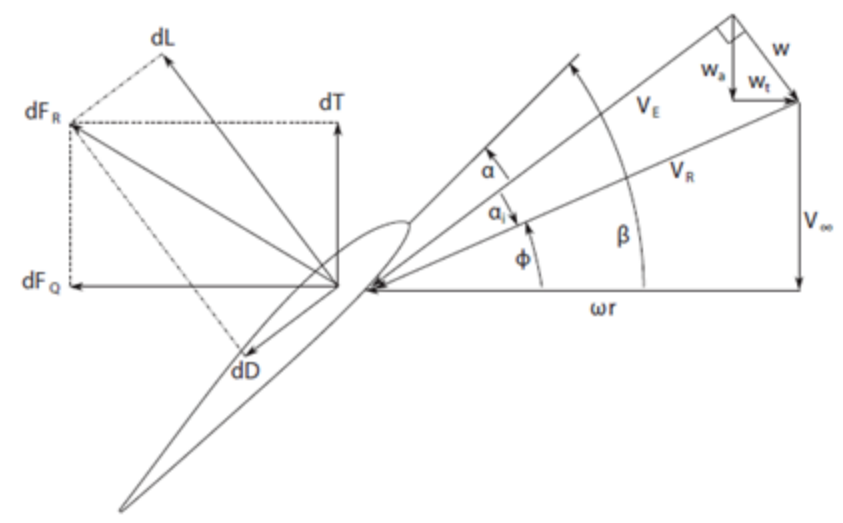

Fig. 1. Blade element of a propeller with the corresponding aerodynamics forces and velocities

Static thrust is the thrust generated by the propeller when the aircraft is in a stationary condition [9]. To obtain the thrust of a propeller, the static thrust test was carried out using the bench test method [10]. In this test, data will also be obtained in the form of propeller rotational speed, power used, and time consumed. Tests for static thrust values are usually varied based on throttle opening, propeller dimensions, and motor type [11]. 


\subsection{Flight Performance of UAV}

Flight performance of UAV can be estimated through theoretical calculations or examined by experimental testing [12]. On the UAV used for fast-flying missions, flight performance parameters such as maximum speed, rate of climb, stall speed, and flight time are important parameters that need to be obtained.

Maximum speed is the speed attained when the maximum thrust is equal to the drag force [13]. To increase the maximum speed of an UAV, the aerodynamic performance of the propeller mainly static thrust value must be increased anyway. It is because the speed of the UAV is directly proportional to the thrust value. The maximum speed of an aircraft can be determined by following equation 1 below [14].

$V_{\text {max }}=\sqrt{\frac{2 F t_{\max }}{C_{D} \cdot \rho \cdot S}}$

The rate of climb is the maximum speed of the vehicle in the vertical axis direction [15]. The rate of climb value determines the length of time of UAV to reach cruising altitude. Theoretically, the rate of climb can be calculated using the following equation 2 .

$R_{O C}=\sqrt{\frac{2\left(F t_{\max }-\mathrm{W} \sin \theta\right)}{C_{D} \cdot \rho \cdot S}} \sin \theta$

For the actual test result, the rate of climb value is obtained from the graph of changes in altitude with respect to time when the vehicle takes off with a certain angle of attack. From the graph, the values for initial altitude, final altitude, and the time spent are next inputted into the following equation 3.

$R_{O C}=\left|\frac{\Delta h}{\Delta t}\right|$

Stall speed is the lowest speed a plane can fly to maintain a level flight. From the perspective of aircraft performance, a higher angle of attack will result in reduced vehicle speed. Stall speed can be calculated using the following equation 4 [14].

$V_{S}=\sqrt{\frac{2 W}{\rho S C_{L}}}$

Flight time is the total time from an aircraft first moving under its power to take off until it comes to rest at the end of the flight. In an electric motor-driven UAVs, the value of flight time is influenced by the capacity of the battery used. The flight time value can be calculated using equation 5 as follows [16].

$t_{f}=\frac{W}{V_{o} \cdot I_{o}} \times 60$ 


\section{Methodology}

\subsection{Specification of Serindit V-2 UAV}

The Serindit V-2 UAV was designed by the research team from Mechanical Engineering, University of Riau. It was designed to take part in the Indonesian Flying Robot Contest (KRTI) for the racing plane category. Table 1 shows the specification data and propulsion system of the Serindit V-2 UAV.

Table 1

Serindit V-2 UAV Specification

\begin{tabular}{lll}
\hline No & Parameter & Specification \\
\hline 1 & Brushless Motor & $900 \mathrm{Kv}$ \\
2 & UAV Type & Fixed Wing \\
3 & Fuselage length & $1060 \mathrm{~mm}$ \\
4 & ESC & Hobbywing 80A \\
5 & Wingspan & $1300 \mathrm{~mm}$ \\
6 & Battery Capacity & $3500 \mathrm{mAh}$ \\
8 & Autopilot & Pixhawk PX4 \\
9 & Total Mass & $2000 \mathrm{gr}$ \\
10 & Material & Hybrid fiberglass-fiber carbon Composite \\
\hline
\end{tabular}

\subsection{Aerodynamic Performance Test of Propeller}

The aerodynamic performance of the propeller is examined through the bench test method. This experimental test is done by measuring the thrust generated by $900 \mathrm{kV}$ electric brushless motor with 5 variant diameters of propeller such as $8,9,10,11,12$ inches. These propellers will be tested consecutively using a lithium polymer battery with the specification of $3500 \mathrm{mAh}$ and 16.8 Volt. Tests were also carried out with varying throttle openings from $50 \%$ to $100 \%$. Each variation is tested until battery voltage down to 12.6 Volt. Figure 2 below shows the process of bench test.

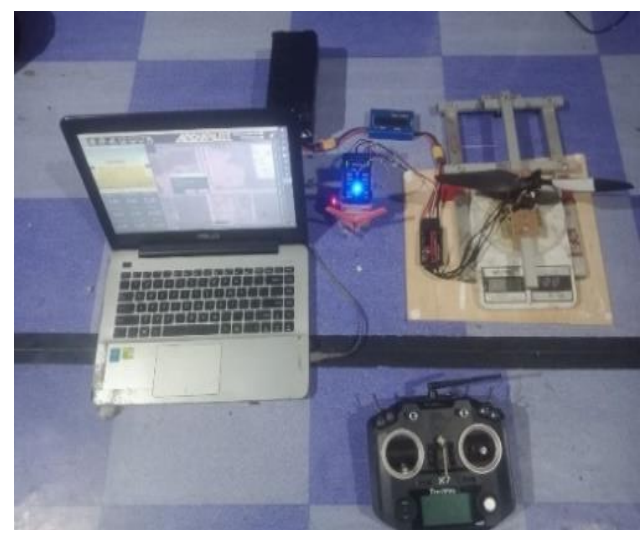

Fig. 2. Process of bench test

\subsection{Flight Performance Calculation of Serindit V-2 UAV}

The maximum speed of the Serindit V-2 UAV is calculated using equation 1 . The maximum speed calculation is done by varying the throttle opening from $50 \%$ to $100 \%$ and the propeller variation starting from 8 inches - 12 inches. In this calculation, the Serindit V-2 UAV is assumed to fly at an altitude of 100 meters above ground level. The thrust force ( $\left.\mathrm{Ft}_{\max }\right)$ value is obtained through the static thrust test data. The drag coefficient $\left(C_{d}\right)$ is 0.0874 (cruise mode), the surface area of the vehicle is $0.9171 \mathrm{~m}^{2}$ and the density of air is $1.225 \mathrm{~kg} / \mathrm{m}^{3}$. Figure 3 below shows Serindit V-2 UAV. 


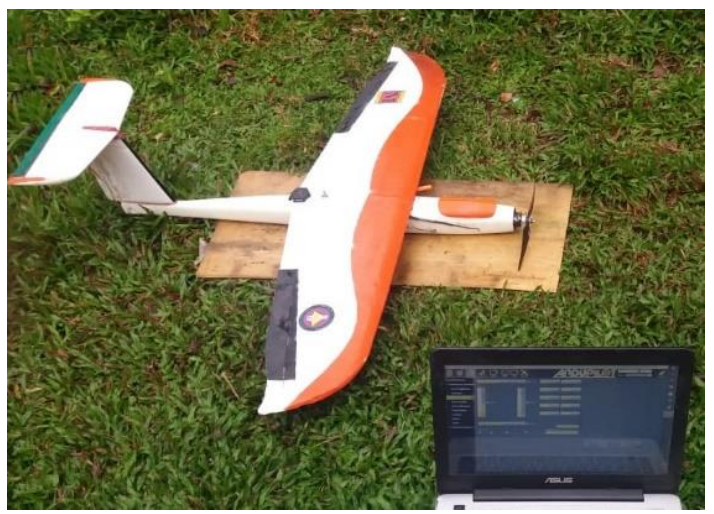

Fig. 3. Serindit V-2 UAV

The rate of climb is the maximum speed of UAVs on the vertical axis. In calculating the rate of climb, the Serindit V-2 UAV is assumed to be an object moving on an inclined plane with an incline angle $(\theta)$ of $16^{\circ}$. This incline angle represents the vehicle's angle of attack when take-off with a throttle value of $100 \%$ and a propeller variation of 8 inches -12 inches. The rate of climb value is carried out using equation 2, the drag coefficient value of 0.29209 (AoA $16^{\circ}$ ), and the total weight's UAV of $19.62 \mathrm{~N}$.

Stall speed is calculated using equation 4. The calculation is carried out when the vehicle takes off with a lift coefficient value of $1.2967\left(\right.$ AoA $\left.16^{\circ}\right)$. Stall speed calculation is also carried out when the UAV series V-2 flies in the cruise phase with a lift coefficient value of $0.5611\left(\right.$ AoA $1^{\circ}$ ).

According to the design target of the Serindit V-2 UAV, the minimum flight time that must be achieved while flying is at least three minutes. The flight time of Serindit V-2 UAV is calculated using equation 5 and the power parameters used are obtained through the static thrust test, while the available power parameters are obtained through the specifications of the battery used $(3,500 \mathrm{mAh}$ 16.8 Volts).

\subsection{Flight Performance Test of Serindit V-2 UAV}

The flight test was carried out based on the most optimum propulsion system performance. The optimum propulsion system performance is determined based on the highest static thrust value and eligible battery consumption time (more than or equal to three minutes). The flight test of Serindit V-2 UAV was carried out in wind conditions with speeds below $1.5 \mathrm{~m} / \mathrm{s}$. Waypoints are created in mission planner software with a straight path of $1 \mathrm{~km}$ back and forth. Throttle opening, cruise altitude (100 meters), and angle of attack at takeoff $\left(16^{\circ}\right)$ are set in the mission planner software. In this test, the speed value of the Serindit V-2 UAV was measured using a digital airspeed sensor connected to a flight controller. During testing, the Serindit V-2 UAV was flown manually to a height of 70 meters above ground level. At an altitude of $70 \mathrm{~m}$, the flight mode of the Serindit V-2 UAV is changed to autonomous, so that the vehicle flies to a cruising altitude of 100 meters. At an altitude of 100 meters above ground level, the Serindit V-2 UAV flies with the following waypoint that has been made until it lands. The flight test was carried out with various throttle values ranging from $50 \%$ to $100 \%$. Figure 4 shows the flight test of the Serindit V-2 UAV. 


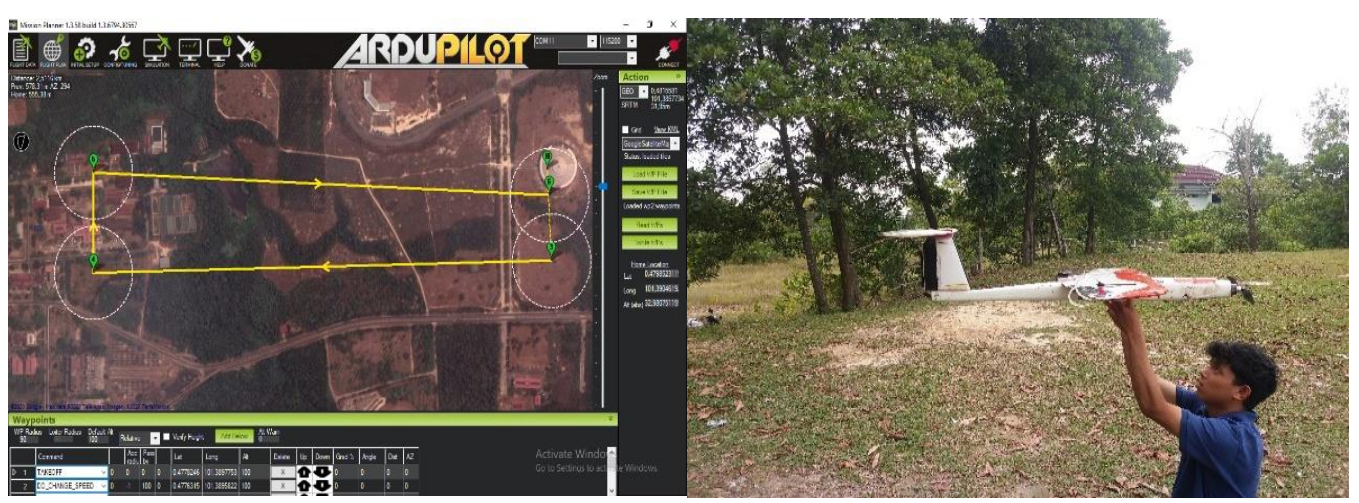

(a)

(b)

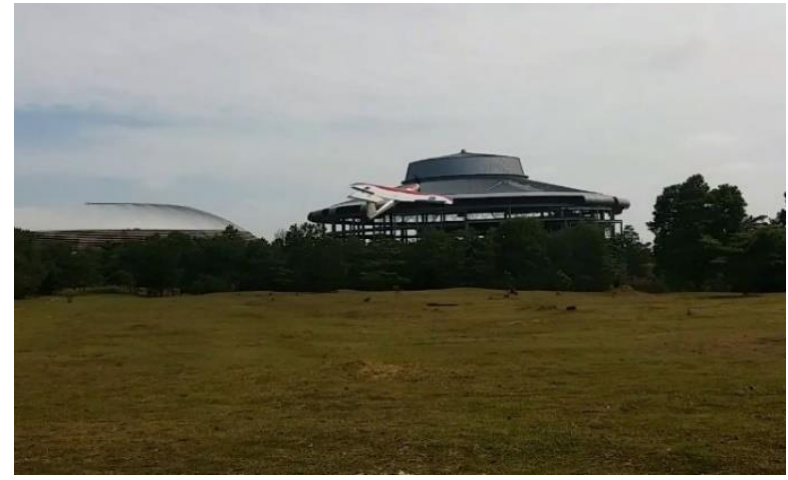

(c)

Fig. 4. Flight test of Serindit V-2 UAV. (a) Waypoint (b) Preflight check (c) Take-off phase

\section{Result and Discussion}

\subsection{Aerodynamic Performance of Propeller}

The aerodynamic performances of propellers related to static thrust value, time consumed, and power consumed are shown in Figure 5, Figure 6, and Figure 7, respectively.

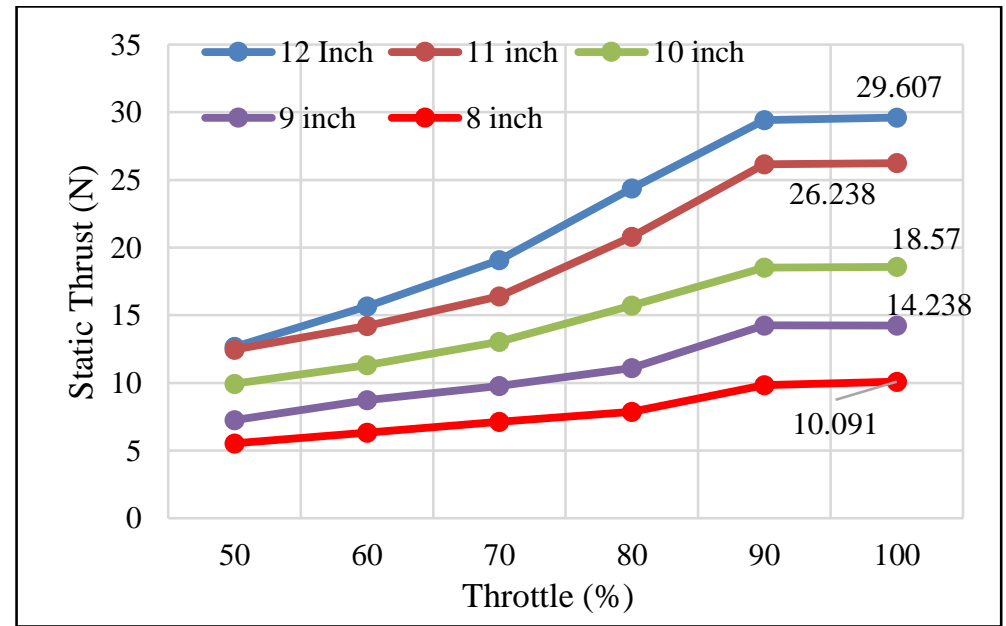

Fig. 5. Static thrust test of the 8 -inch to 12 -inch propeller graph 


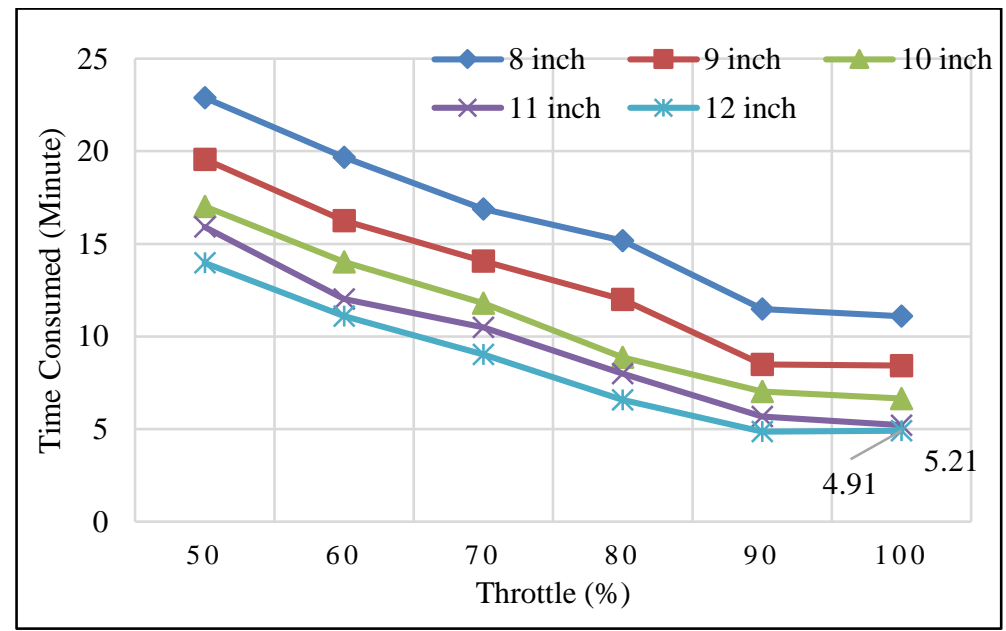

Fig. 6. Time consumed vs throttle of Serindit V-2 UAV

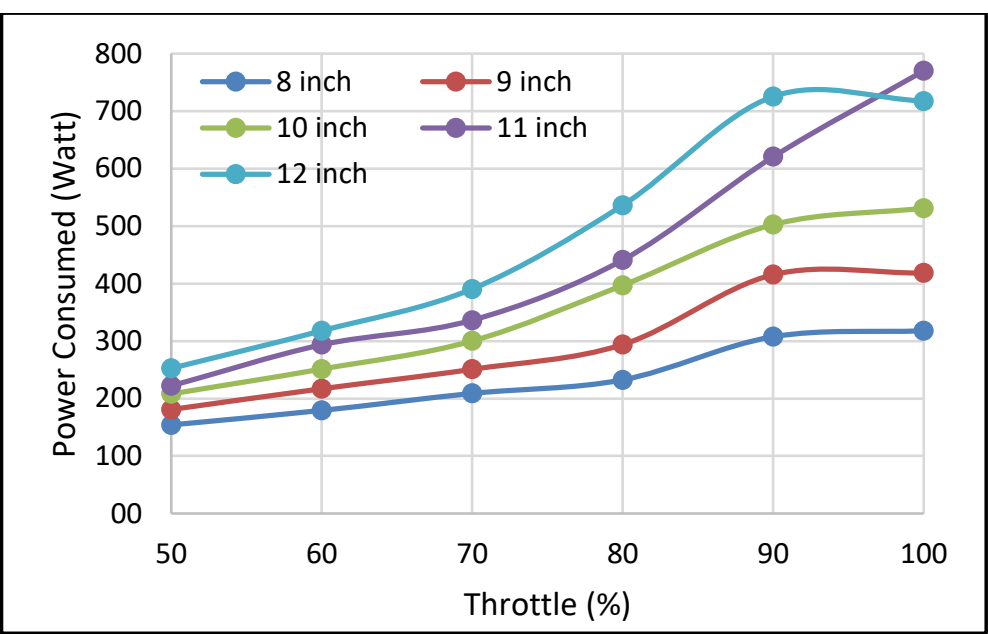

Fig. 7. Power consumed vs throttle of Serindit V-2 UAV

The propulsion system with the 8-inch to 12 -inch propeller generated the maximum thrust of $10.091 \mathrm{~N}, 14.238 \mathrm{~N}, 18.57 \mathrm{~N}, 26.238 \mathrm{~N}$, and $29.607 \mathrm{~N}$, respectively. In accordance with the design prerequisite of fixed-wing type UAV for high-speed missions, the static thrust value is should be greater than the total weight of the UAV. Thus, 8-inch, 9-inch, and 10-inch propellers are not recommended for the propulsion system of Serindit V-2 UAV.

The trend of the time consumed and power consumed shown in Figure 6, is inversely proportional to the dimensions of the propeller used. It is due to the larger the size of the propeller, the greater both the value of the thrust generated and the electrical power used. Increased use of electrical power automatically reduces the time consumed by the battery. Figure 6 also shows that the propulsion system with 11 -inch and 12 -inch propellers at $100 \%$ throttle produces time consumed of 5.21 minutes and 4.91 minutes, respectively. The small difference value of time consumed/power consumed and the significant difference value of static thrust shows that the propulsion system with the 12 -inch propeller has the most optimal aerodynamic performance.

\subsection{Maximum Speed Calculation Result}

Figure 8 shows a graph of the maximum speed concerning throttle opening value on a propeller variation of 8 inches -12 inches. 


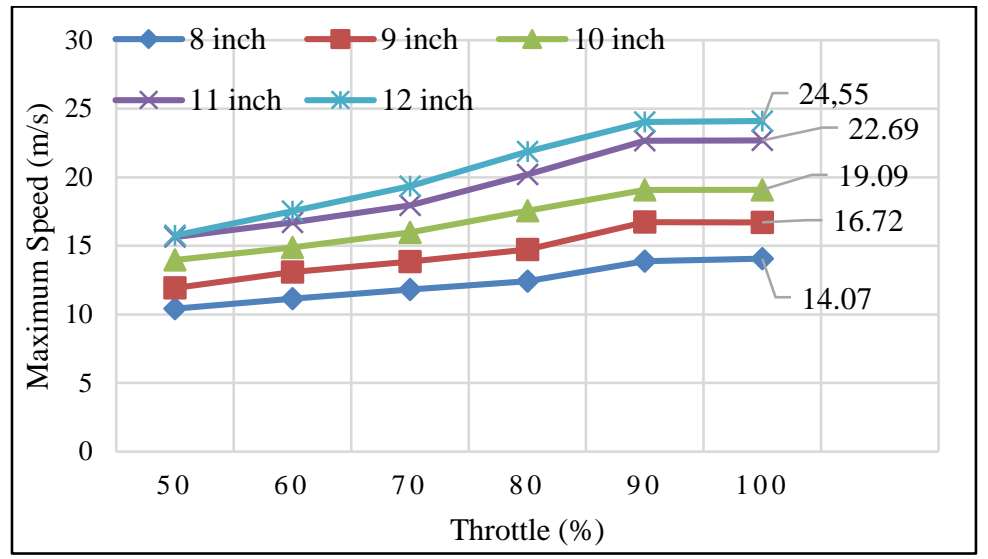

Fig. 8. Maximum speed vs throttle value of Serindit V-2 UAV

The trend graph shown in Figure 8, shows conformity with the trend of static thrust value in Figure 5. This is because the greater the value of static thrust, the greater the maximum speed that can be achieved by the Serindit V-2 UAV. In Figure 8 , the propulsion system with a 12 -inch propeller at a throttle of $100 \%$ is capable to produce a maximum speed of $24.55 \mathrm{~m} / \mathrm{s}$.

\subsection{Rate of Climb Calculation Result}

Figure 9 shows the rate of climb calculation result for 8-inch to 12 -inch propeller.

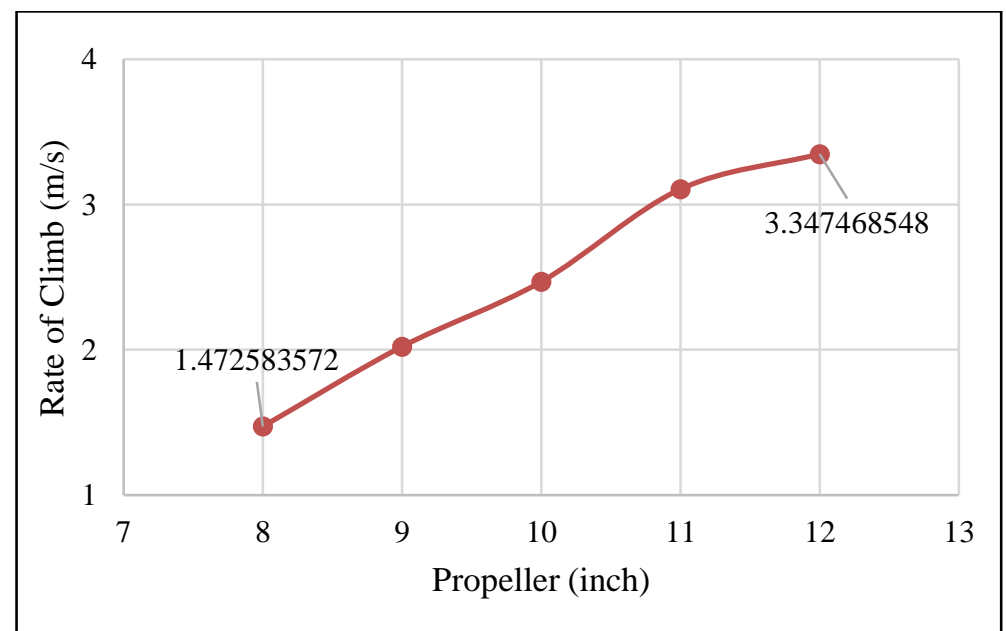

Fig. 9. Rate of climb vs propeller diameter

To prevent stalls caused by the insufficient thrust generated by the propulsion system, the throttle value is set to be $100 \%$. Therefore, the rate of climb calculation does not vary the throttle value. From Figure 9, it can be seen that the highest rate of climb of Serindit V-2 UAV is $3.34 \mathrm{~m} / \mathrm{s}$, occurring on a 12-inch propeller.

\subsection{Stall Speed Calculation Result}

Table 2 shows the stall speed calculation result of the Serindit V-2 UAV. It can be seen from Table 2 , at the cruise phase, the Serindit V-2 UAV speed must be more than $14,602 \mathrm{~m} / \mathrm{s}$ so that it does not experience a stall. On the take-off phase, the UAV speed must be more than $9.06 \mathrm{~m} / \mathrm{s}$. 
Table 2

Result of Stall Speed Calculation

\begin{tabular}{ll}
\hline Mode & Stall Speed $(\mathrm{m} / \mathrm{s})$ \\
\hline Take-off phase $\left({\left.\mathrm{AoA} 16^{\circ}\right)}\right.$ ) \\
Cruise phase (AoA $\left.1^{\circ}\right)$ & 14.602 \\
\hline
\end{tabular}

\subsection{Maximum Speed Test Result}

Figures 10 show the flight test results in the form of speed values at each throttle opening varies from $50 \%$ to $100 \%$.

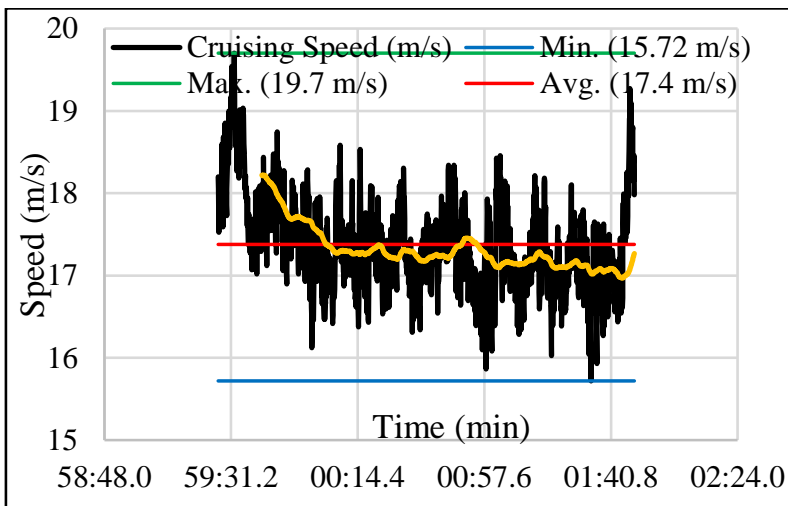

(a)

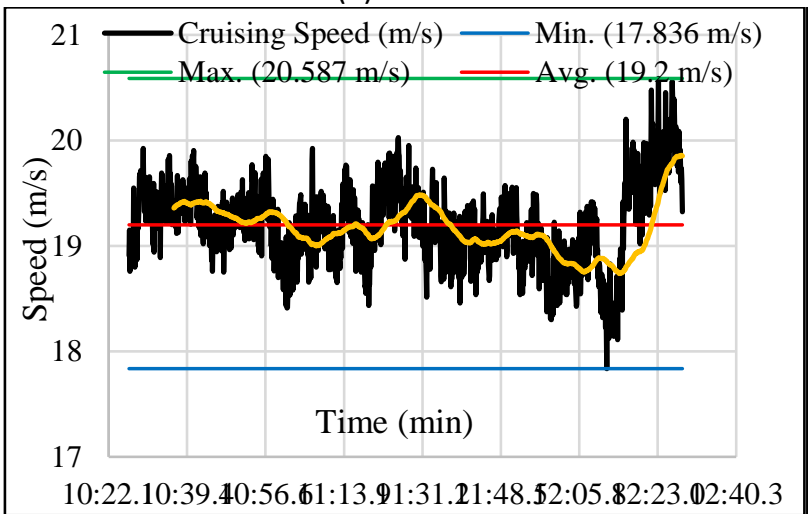

(c)

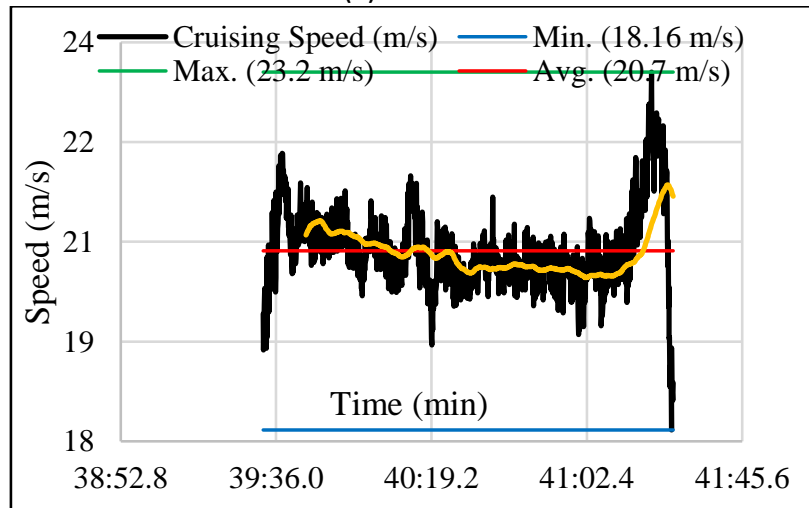

(e)

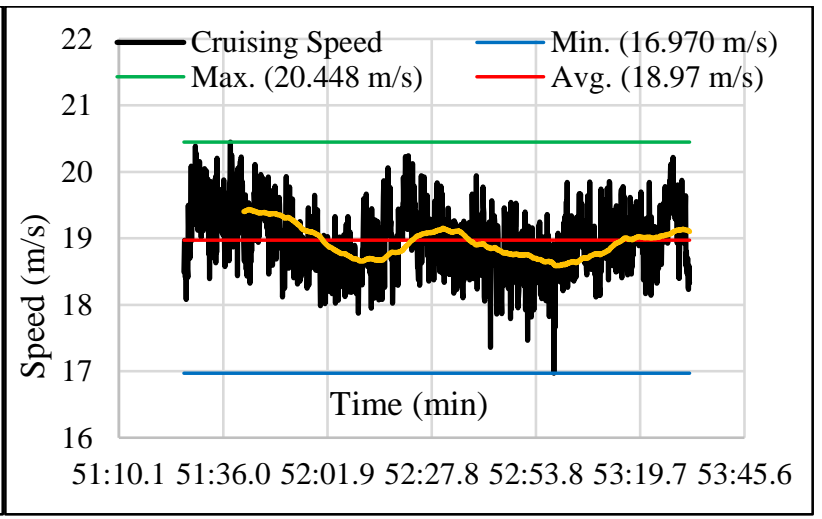

(b)

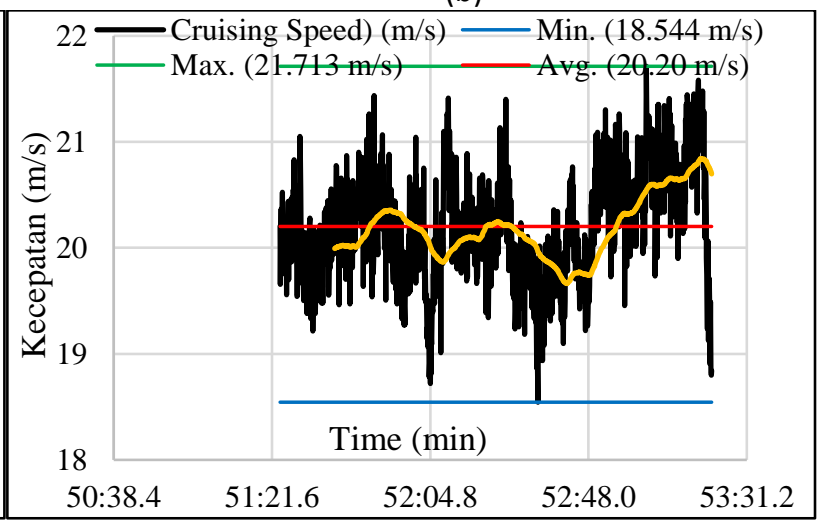

(d)

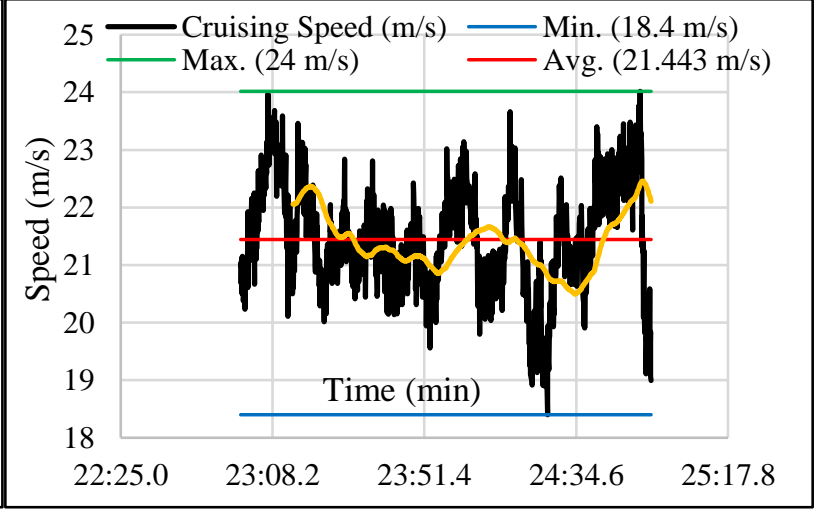

(f)

Fig. 10. Speed vs Time graph (a) Throttle $50 \%$ (b) Throttle 60\% (c) Throttle $70 \%$ (d) Throttle $80 \%$ (e) Throttle 90\% (f) Throttle 10\% 
Figure 10 shows that the maximum speed of Serindit V-2 UAV cannot be maintained continuously. This is related to wind conditions and the vehicle's maneuver when turning to the home position. The actual maximum speed value is then compared with the theoretical maximum speed value as shown in Table 3.

Table 3

Comparison of the theoretical and actual maximum speed value

\begin{tabular}{|c|c|c|c|c|}
\hline \multirow[t]{2}{*}{ Throttle \% } & \multicolumn{4}{|c|}{ Maximum Speed (m/s) } \\
\hline & Actual & Actual Average & Theoretical & Difference \\
\hline \multirow[t]{3}{*}{50} & 20.053 & 19.959 & 15.76 & 4.199 \\
\hline & 19.701 & & & \\
\hline & 20.123 & & & \\
\hline \multirow[t]{3}{*}{60} & 20.448 & 20.464 & 17.53 & 2.934 \\
\hline & 20.541 & & & \\
\hline & 20.403 & & & \\
\hline \multirow[t]{3}{*}{70} & 20.587 & 20.600 & 19.35 & 1.25 \\
\hline & 20.098 & & & \\
\hline & 21.116 & & & \\
\hline \multirow[t]{3}{*}{80} & 21.965 & 21.865 & 21.87 & 0.005 \\
\hline & 21.713 & & & \\
\hline & 21.918 & & & \\
\hline \multirow[t]{3}{*}{90} & 23.183 & 23.388 & 24.04 & 0.652 \\
\hline & 23.760 & & & \\
\hline & 23.222 & & & \\
\hline \multirow[t]{3}{*}{100} & 24.017 & 24.562 & 24.55 & 0.012 \\
\hline & 24.801 & & & \\
\hline & 24.867 & & & \\
\hline
\end{tabular}

Based on Table 3, the propulsion system of Serindit V-2 UAV with 50\% - 100\% throttle produce average maximum speed of $19.959 \mathrm{~m} / \mathrm{s}, 20.464 \mathrm{~m} / \mathrm{s}, 20.6 \mathrm{~m} / \mathrm{s}, 21.86 \mathrm{~m} / \mathrm{s}, 23.388 \mathrm{~m} / \mathrm{s}$ dan 24.562 $\mathrm{m} / \mathrm{s}$. The difference between the calculation results and the test result looks relatively small at $70 \%$ to $100 \%$ throttle opening, while at $50 \%$ and $60 \%$ throttle the difference tends to be larger. This is due to the remaining initial speed generated when the vehicle takes off with a throttle of $100 \%$.

\subsection{Rate of Climb Test Result}

The rate of climb is measured when the Serindit V-2 UAV begins to change to autonomous mode, which is at an altitude of 70 meters above the ground. Figure 11 shows a graph of altitude vs time. Figure 11 shows initial altitude, final altitude, and climb time are 70.639 meters, 104.22 meters and 8.4 seconds, respectively. These three values are then substituted to equation 3 . Its result rate of climb at the take-off of $3.998 \mathrm{~m} / \mathrm{s}$. It's then compared to the theoretical rate of climb of $3.347 \mathrm{~m} / \mathrm{s}$ so that a difference of $0.651 \mathrm{~m} / \mathrm{s}$ is obtained. The difference in the rate of climb value is caused by several factors. The first factor is the wind condition. Although before the test the wind condition remained at $1 \mathrm{~m} / \mathrm{s}$, it doesn't guarantee the wind conditions will be consistent during the test. The second factor is the design of the Serindit V-2 UAV airframe. Holistically, the airframe is considered seamless, however, in actual conditions, some complex parts of the fuselage and wings have relative taper shape, or slightly wavy. This of course causes a difference in the value of the actual drag coefficient that affects the rate of climb. 


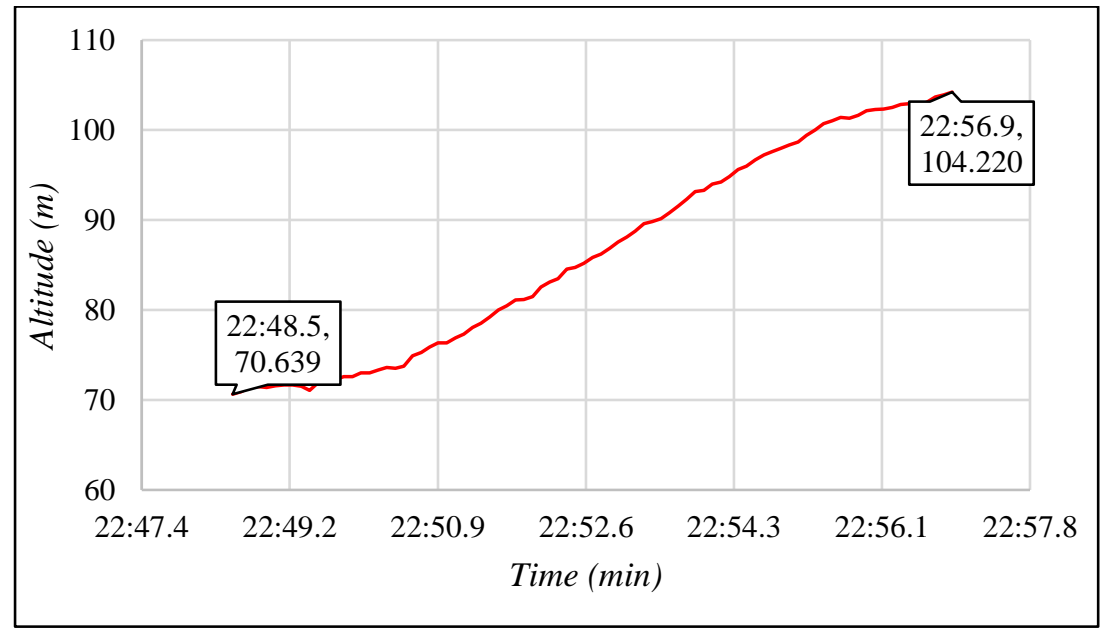

Fig. 11. Altitude vs time

\subsection{Stall Speed Test Result}

The stall speed of the Serindit V-2 UAV was carried out with $50 \%$ throttle, which is the lowest throttle during the test. The stall speed is obtained when the Serindit V-2 UAV begins to lose altitude, while the behavior of the vehicle remains in a level condition. This level condition can be seen on the aircraft pitch which is stable around $1^{0}$. Figure 12 shows a graph of the vehicle's flight altitude, pitch angle, and speed of the Serindit V-2 UAV during the stall phase.

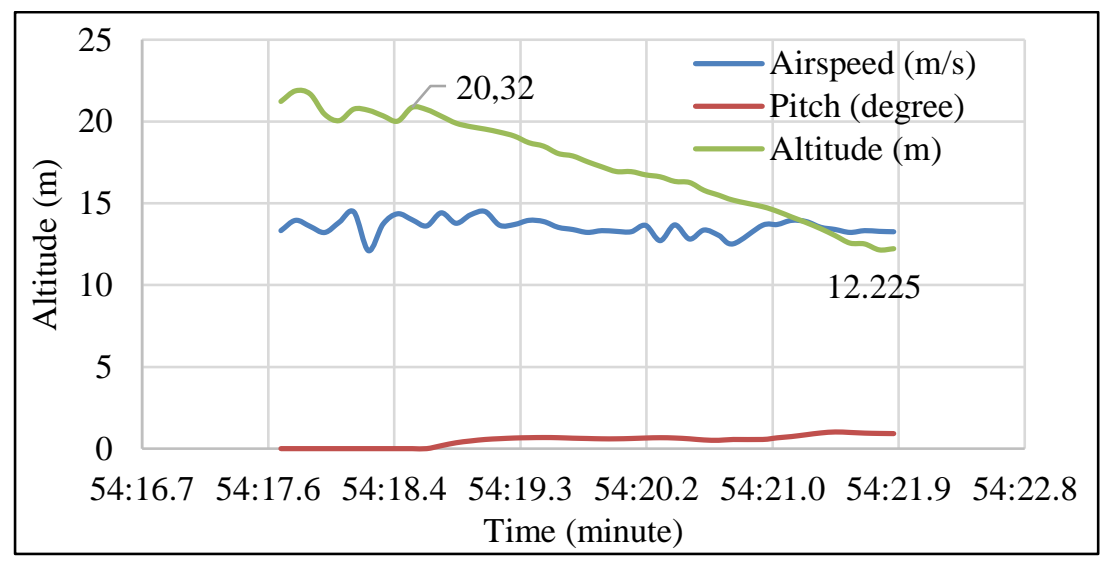

Fig. 12. Stall Condition Phase

From Figure 12, it can be seen that at an altitude of 20.32 meters, the Serindit V-2 UAV began to experience a decrease in altitude, without a significant change in pitch angle. This shows that the stall speed of the Serindit V-2 UAV on the level condition (cruise phase) is $13 \mathrm{~m} / \mathrm{s}$. If we compare the actual stall speed value (cruise) with the theoretical stall speed $(14.602 \mathrm{~m} / \mathrm{s})$, there is a difference of 1.602 $\mathrm{m} / \mathrm{s}$.

\subsection{Flight Time Test Result}

The actual flight time value is obtained from the time difference that occurs when the vehicle starts takeoff to landing. Figure 13 shows a graph of the flight phase of the Serindit V-2 UAV from takeoff to landing. 


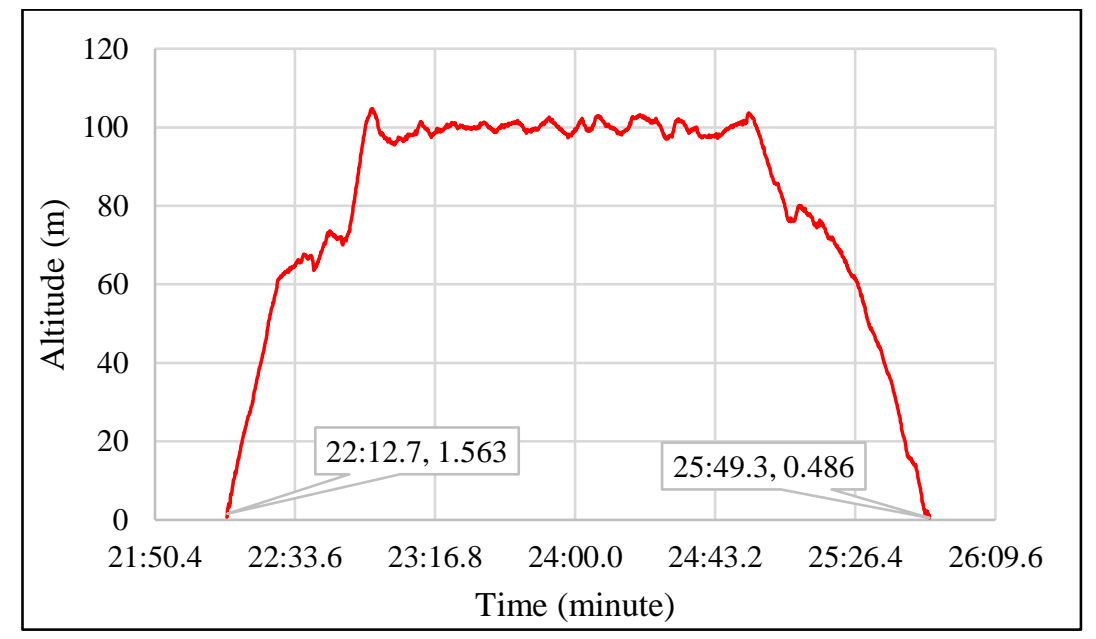

Fig. 13. UAV Flight Phase

From Figure 13, it can be seen that the Serindit UAV started to take off at the $22^{\text {nd }}$ minute 12 seconds and landed at the $25^{\text {th }}$ minute 49 seconds. This shows that the flight time value of the Serindit V-2 UAV when flying with $100 \%$ throttle is 3 minutes 27 seconds. When compared with the theoretical flight time value (4.91 minutes), there is a difference of 1.46 minutes.

\section{Conclusion}

The conclusions that can be drawn from the research on the performance analysis of the propulsion system of Serindit V-2 UAV are as follows

i. From the bench test test results, the optimum aerodynamic performance is generated by the 12 -inch propeller and $100 \%$ throttle opening with the thrust value of $29.607 \mathrm{~N}$, time consumed of 4.91 minutes, and power consumed of 717.57 Watt.

ii. From the flight performance calculation result, the 12 -inch propeller with $100 \%$ throttle opening, produces the best performance with a maximum speed value of $24.55 \mathrm{~m} / \mathrm{s}$, rate of climb of $3,347 \mathrm{~m} / \mathrm{s}$, and the stall speed of $14.602 \mathrm{~m} / \mathrm{s}$.

iii. From the flight performance test result, the 12 -inch propeller with $100 \%$ throttle opening, produces the maximum speed of $24.56 \mathrm{~m} / \mathrm{s}$, a climb rate of $2.65 \mathrm{~m} / \mathrm{s}$, the flight time of 3 minutes 27 seconds, and the stall speed of $13 \mathrm{~m} / \mathrm{s}$. This shows that the difference between the actual and theoretical performance values is not too significant.

\section{References}

[1] Sadraey, Mohammad H. Design of Unmanned Aerial Systems. John Wiley \& Sons, 2020. https://doi.org/10.1002/9781119508618

[2] Zohary, Aideal Czar, Waqar Asrar, and Mohammed Aldheeb. "Numerical Investigation on the Pressure Drag of Some Low-Speed Airfoils for UAV Application." CFD Letters 13, no. 2 (2021): 29-48. https://doi.org/10.37934/cfdl.13.2.2948

[3] Culpepper, Grace G., Jielong Cai, and Sidaard Gunasekaran. "Propeller and Propeller-in-Wing Thrust Vectoring." In AlAA Scitech 2021 Forum, p. 0615. 2021. https://doi.org/10.2514/6.2021-0615

[4] Austin, Reg. Unmanned aircraft systems: UAVS design, development and deployment. Vol. 54. John Wiley \& Sons, 2011. https://doi.org/10.1002/9780470664797

[5] A. Dr.R., M. J., and M. E., "Seed Dropping UAV: Design of Seed Dropping UAV in Afforestation," larjset 8, no. 6 (2021): 490-494. https://doi.org/10.17148/IARJSET.2021.8687

[6] Anuar, Kaspul, Warman Fatra, and Musthafa Akbar. "Tricopter Vehicle Frame Structure Design Integrated as Platform of Fixed Wing Atha Mapper 2150." Journal of Ocean, Mechanical and Aerospace-science and engineering- 64, no. 2 (2020): 68-72. https://doi.org/10.36842/jomase.v64i2.218 
[7] Anuar, K., and M. Akbar. "Wing design of uav serindit v-1." In IOP Conference Series: Materials Science and Engineering, vol. 539, no. 1, p. 012002. IOP Publishing, 2019. https://doi.org/10.1088/1757-899X/539/1/012002

[8] Pusat Prestasi Nasional Kemdikbud RI, Buku Panduan Kontes Robot Terbang Indonesia. Jakarta: Kemdikbud RI, 2020.

[9] Yang, Chun Lei, Ling Zhou, Nan Zhang, and Hong Guang Jia. "Analysis of Propeller Static Thrust Estimation Method." In Applied Mechanics and Materials, vol. 397, pp. 475-478. Trans Tech Publications Ltd, 2013. https://doi.org/10.4028/www.scientific.net/AMM.397-400.475

[10] Avanzini, Giulio, Attilio Di Nisio, A. M. L. Lanzolla, and D. Stigliano. "A test-bench for battery-motor-propeller assemblies designed for multirotor vehicles." In 2020 IEEE 7th International Workshop on Metrology for AeroSpace (MetroAeroSpace), pp. 600-605. IEEE, 2020. https://doi.org/10.1109/MetroAeroSpace48742.2020.9160320

[11] Othman, M. N. K., Z. M. Razlan, Z. A. Wahid, A. B. Shahriman, I. Zunaidi, Wan Khairunizam, and N. Z. Noriman. "Experimental study of UAV propeller Thrust generation for various Propeller Blade-Span and the relation with mouth-ring." In IOP Conference Series: Materials Science and Engineering, vol. 557, no. 1, p. 012052. IOP Publishing, 2019. https://doi.org/10.1088/1757-899X/557/1/012052

[12] Kontogiannis, Spyridon G., and John A. Ekaterinaris. "Design, performance evaluation and optimization of a UAV." Aerospace science and technology 29, no. 1 (2013): 339-350. https://doi.org/10.1016/i.ast.2013.04.005

[13] Fahlstrom, Paul, and Thomas Gleason. Introduction to UAV systems. John Wiley \& Sons, 2012. https://doi.org/10.1002/9781118396780

[14] Liu, Rui-lin, Zhong-jie Zhang, Yu-fei Jiao, Chun-hao Yang, and Wen-jian Zhang. "Study on flight performance of propeller-driven UAV." International Journal of Aerospace Engineering 2019 (2019). https://doi.org/10.1155/2019/6282451

[15] Bravo-Mosquera, Pedro David, Laura Botero-Bolivar, Daniel Acevedo-Giraldo, and Hernán Darío Cerón-Muñoz. "Aerodynamic design analysis of a UAV for superficial research of volcanic environments." Aerospace Science and Technology 70 (2017): 600-614. https://doi.org/10.1016/i.ast.2017.09.005

[16] Dündar, Özgür, Mesut Bilici, and Tarık Ünler. "Design and performance analyses of a fixed wing battery VTOL UAV." Engineering Science and Technology, an International Journal 23, no. 5 (2020): 1182-1193. https://doi.org/10.1016/i.jestch.2020.02.002 